\title{
PENGARUH IKLAN MAKANAN/MINUMAN/SUPLEMEN VITAMIN-MINERAL DI TV TERHADAP POLA KONSUMSI REMAJA DI WILAYAH JAKARTA TIMUR
}

\author{
${ }^{1}$ Lely Wahyuniar, ${ }^{2}$ L. Karyadi \\ ${ }^{1}$ STIKes Kuningan, ${ }^{2}$ Institut Pertanian Bogor \\ wahyuniarl@unaids.org
}

\begin{abstract}
Abstrak
Saat ini, iklan makanan di TV dapat mempengaruhi pola konsumsi remaja. Penelitian ini bertujuan mengetahui pengaruh iklan makanan/minuman/suplemen di TV terhadap frekuensi konsumsi remaja. Penelitian potong-lintang ini mengambil sampel dari 82 remaja, laki-laki dan perempuan usia 15-17 tahun di Jakarta Timur dipilih secara acak dari sekolah menengah negeri. Pengamatan awal dilakukan untuk mengetahui jenis iklan makanan di TV serta perkiraan harga produk yang diiklankan. Penelitian utama berupa wawancara mendalam terhadap remaja dan manajer iklan TV. Hasil studi menunjukkan terdapat hubungan antara durasi menonton TV, sikap terhadap iklan, pengetahuan gizi, jumlah uang saku serta lama waktu bermain dengan teman terhadap frekuensi konsumsi produk yang diiklankan. Laki-laki mengkonsumsi lebih banyak makanan/minuman yang bernutrisi rendah daripada perempuan sedangkan perempuan cenderung mengkonsumsi lebih banyak produk bernutrisi (termasuk suplemen) daripada laki-laki. Regulasi kuat diperlukan untuk mengatur penayangan iklan produk tersebut di TV sekaligus peningkatan edukasi bagi remaja untuk membangun pola konsumsi makanan yang sehat.
\end{abstract}

Kata Kunci: Iklan TV; Makanan; Minuman; Suplemen Vitamin-Mineral; Pola Konsumsi.

\section{Pendahuluan}

Laju epidemi overweight dan obesitas yang terus meningkat masih menjadi permasalahan kesehatan masyarakat yang utama. Orang dari berbagai kalangan usia, $13 \%$ diantaranya adalah dewasa, mengalami overweight atau memenuhi kriteria obesitas. Secara global, lebih dari 300 juta remaja usia 5-19 tahun terdiagnosis overweight dan obesitas (WHO, 2017). Di Indonesia, terdapat $20 \%$ remaja laki-laki dan $35 \%$ remaja mengalami obesitas. Obesitas dapat disebabkan oleh banyak faktor, seperti banyaknya konsumsi makanan berkadar gula dan lemak tinggi serta rendah serat (Kemenkes RI, 2014).

Masa remaja merupakan periode penting dalam daur kehidupan. Pada masa 
JURNAL ILMU KESEHATAN BHAKTI HUSADA:

HeALTH SCIENCES JOURNAL, Vol. 10 No. 01, JUNI 2019 DOI:

remaja terjadi pengembangan karakteristik perubahan sosial seperti peningkatan pengaruh pergaulan teman sebaya, pencarian jati diri dan kebebasan, lebih memperhatikan penampilan, aktivitas yang padat, dimana semua itu dapat mempengaruhi asupan gizi dan preferensi makanan (Hurlock, n.d.). Asupan nutrisi dan perilaku makan pada periode kehidupan ini menentukan kebiasaan makan seumur hidup dan dapat mengembangkan faktor risiko penyakit kronis saat dewasa. Alasan utama yang mendasari pilihan makanan di kalangan remaja adalah pola konsumsi dan preferensi rasa. Proses pemilihan makanan merupakan proses kompleks yang melibatkan banyak faktor seperti budaya, sosio-ekonomi dan agama. Selain itu, di era globalisasi kini tersedia lebih banyak pilihan makanan yang bisa mempengaruhi pola konsumsi mereka (Bargiota \& et al., 2013).

$$
\text { Media berperan dalam }
$$

mempengaruhi aspek kognitif, afektif dan perilaku di masyarakat (Richard, Paul, \& Anne-marie, 2017). Televisi sebagai media yang memberikan tampilan audio-visual, lebih menarik dalam memberikan informasi kepada khalayak dibandingkan tipe media komunikasi lainnya. Iklan di TV berperan memperkenalkan produk dengan memperkuat pemahaman terhadap produk dan mendorong orang untuk membelinya. Televisi masih menjadi metode yang paling dominan dalam mengiklankan makanan dan minuman terhadap remaja. Iklan makanan tersebut tidak hanya menjadikan remaja sebagai target, tetapi juga customerbranding (Arcan, Bruening, \& Story, 2014). Studi terbaru mengatakan bahwa iklan makanan di TV berkaitan dengan preferensi dan perilaku terhadap produk yang diiklankan. Hal ini, tentu saja, berperan penting terhadap sikap remaja dalam memilih makanan (Eni-harari \& Eyal, 2019). Penelitian Eyal et al. (2016) menunjukkan bahwa makanan yang paling umum diiklankan adalah permen, minuman ringan dan produk susu sedangkan buah-buahan dan sayuran lebih jarang diiklankan (Eyal \& et al., 2016).

Penelitian sebelumnya telah mengatakan terdapat hubungan positif antara konsumsi makanan dan durasi menonton TV (Collings, 2018). Sikap dan persepsi remaja terhadap makanan tidak sehat secara signifikan berkorelasi dengan iklan makanan yang tidak sehat, tetapi dampaknya dapat dikurangi jika iklan tersebut ditayangkan bersama dengan iklan makanan sehat. Iklan produk makanan juga memiliki dampak yang besar terhadap permintaan pasar dan perilaku pembeli. Daya konsumsi terhadap makanan yang harganya melonjak berakibat orang cenderung lebih sedikit mengkonsumsi makanan tersebut (Arcan et al., 2014). 
JURNAL ILMU KESEHATAN BHAKTI HUSADA:

HEALTH SCIENCES JOURNAL, Vol. 10 No. 01, JUNI 2019 DOI:
Penelitian-penelitian terkait pola konsumsi pada umumnya lebih difokuskan pada anak-anak dan masih jarang dilakukan di Indonesia. Oleh karena itu timbul kebutuhan untuk meneliti faktor-faktor yang mempengaruhi pola konsumsi pada remaja yang banyak terpapar oleh iklan makanan/minuman/suplemen vitaminmineral di TV. Tujuan penelitian ini adalah mengetahui hubungan antara durasi menonton TV, sikap terhadap iklan, pengetahuan gizi, status sosial-ekonomi (jumlah uang saku, gender dan durasi bermain bersama teman) dengan frekuensi konsumsi makanan/minuman/suplemen vitamin-mineral yang diiklankan.

\section{Metode}

\section{Subjek.}

Penelitian ini dilakukan selama periode Desember 1994 - Februari 1995. Sebanyak 80 remaja usia 15-17 tahun dipilih secara acak dari sekolah menengah negeri. Sampel diambil dari 4 kelas tingkat pertama, masing-masing sebanyak 20 responden dipilih secara acak dengan jumlah laki-laki dan perempuan sama. Waktu sekolah responden adalah sore hari (pukul 12.3017.30). Responden mengikuti kegiatan ekstrakurikuler sekitar 2-3 kali per minggu di pagi hari. Sekolah tersebut terletak di dekat pusat perbelanjaan yang di dalamnya terdapat beberapa restoran makanan cepat saji seperti Kentucky Fried Chicken dan outlet makanan lainnya, serta terletak di dekat halte bus. Di kantin sekolah dijumpai makanan ringan tradisional (roti manis, pisang goreng, kue-kue kecil), minuman ringan dan permen. Terdapat juga pedagang bakso, mie dan cocktail buah yang berjualan di sekitar sekolah.

Pengumpulan Data.

Studi awal dilakukan untuk mengobservasi jenis iklan makanan/minuman/suplemen vitaminmineral yang ditayangkan di TV dalam rentang waktu hari dan jenis program yang berbeda. Informasi yang diperoleh dapat membantu memutuskan produk mana yang akan dimasukkan dalam penelitian. Penelitian utamanya sendiri menggunakan dua jenis kuesioner. Kuesioner pertama berisi beberapa pertanyaan terbuka dan tertutup untuk mengetahui karakteristik remaja seperti status sosial-ekonomi, pola makan dan sikap terhadap iklan. Kuesioner kedua berisi pertanyaan terbuka untuk mendapatkan informasi durasi penayangan iklan makanan/minuman/suplemen vitaminmineral yang ditampilkan selama periode tiga bulan pengamatan, yang ditanyakan ke manajer stasiun TV (RCTI dan SCTV) .

Jenis produk

makanan/minuman/vitamin-mineral suplemen yang diiklankan yaitu coklat (Silver Queen); permen (Relaxa dan Vicks); makanan cepat saji (Kentucky Fried 
JURNAL ILMU KESEHATAN BHAKTI HUSADA:

HeALTH SCIENCES JOURNAL, Vol. 10 No. 01, JUNI 2019 DOI:
Chicken/KFC, McDonalds, Pizza Hut); mie (Indomie/Supermie); minuman ringan (Coca-Cola dan Teh Botol); susu (Dancow/Frisian Flag); suplemen vitaminmineral (Xon-ce, Caxon-F, CDR).

\section{Analisis Data.}

Analisis data mencakup statistik deskriptif dan inferensial. Uji statistik yang dilakukan adalah T-Test Independen dan One-Way ANOVA untuk menganalisis variabel kontinu (terdistribusi normal) dan variabel berskala kategorik dengan dua kelompok/lebih. Pengujian variabel kontinu yang tidak terdistribusi normal dengan variabel berskala kategorik menggunakan Uji Mann-Whitney dan Uji Kruskal-Wallis. Sementara data berskala kategorik dianalisis menggunakan uji Chi-Square dan uji Fisher Exact. Perangkat lunak yang digunakan dalam penelitian ini adalah Epi-Info versi 5.0.1 dan SPSS.

\section{Hasil}

\section{Profil Remaja.}

Sebagian besar responden berusia 15 tahun (66.3) dan semuanya berasal dari kelas 10 SMA. Hobi mereka adalah memainkan alat musik/mendengarkan musik (55\%) dan olahraga (33.8\%). Sebagian besar meluangkan waktu untuk melakukan hobi mereka sekitar 2 jam pada hari sekolah (56.3\%) dan lebih dari 3 jam di akhir pekan (62.5\%). Waktu yang dihabiskan bersama teman di sekolah rata-rata selama 2 jam per hari $(46.3 \%)$ untuk bermain game (35\%), hanya mengobrol $(32.5 \%)$ atau makan bersama-sama (10\%); namun menjadi lebih dari 3 jam di akhir pekan (62.5\%). Semua siswa berasal dari kelas ekonomi menengah. Pekerjaan utama ayah responden adalah karyawan swasta (35\%) dan pegawai negeri sipil $(33.8 \%)$ tetapi pekerjaan ibu mereka sebagian besar adalah ibu rumah tangga (73.8\%). Mayoritas latar belakang pendidikan orangtua mereka adalah lulusan SMA. Jumlah rata-rata uang saku yang diterima dari orangtua per hari adalah $\mathrm{Rp}$ 20,000,- yang berkisar antara Rp. 10,000,sampai dengan Rp 50,000,-.

\section{Paparan terhadap Iklan di TV}

Semua responden memiliki TV di rumah. Sebagian besar menonton TV selama 4 jam per hari pada hari sekolah (44\%) dan lebih dari 4 jam (60\%) pada akhir pekan. Program TV favorit di kalangan remaja adalah "Anak Jalanan" (60\%), "Mermaid in Love" (30\%), "Tuyul dan Mba Yul Reborn" (25\%) dan Program Musik, 25\%. Program TV tersebut semua disiarkan pada waktu tayang yang utama. Pada program "Putri Yang Ditukar" (durasi jam) ditampilkan beberapa iklan dan $50 \%$ diantaranya merupakan iklan makanan, yang artinya bahwa remaja terpapar iklan makanan/minuman/suplemen vitaminmineral tersebut selama 6 menit per jamnya. 
JURNAL ILMU KESEHATAN BHAKTI HUSADA:

HeALTH SCIENCES JouRnAL, Vol. 10 No. 01, JUNI 2019 DOI:
Ciptaan disebarluaskan di bawah Lisensi Creative Commons AtribusiNonKomersial-BerbagiSerupa 4.0 Internasional.
Makanan yang paling banyak diiklankan di televisi selama penayangan program favorit mereka dalam rentang waktu tiga bulan tersebut adalah Relaxa (15 kali), Teh Botol (14 kali) dan mie (10 kali). Dalam periode yang sama, total penayangan iklan makanan/ minuman/suplemen vitamin-mineral tersebut adalah 102 kali untuk Relaxa, 261 kali untuk Teh Botol (Coca-Cola hanya 58 kali), 120 kali untuk mie, 68 kali untuk Pizza Hut dan 108 kali untuk Kentucky Fried Chicken (lihat Tabel 1).

\section{Tabel 1. Distribusi Frekuensi Konsumsi Makanan/Minuman/Suplemen Vitamin- Mineral yang Diiklankan di TV, Partner Konsumsi Makanan, Tempat Makan, Frekuensi Penayangan Iklan dan Sumber Informasi}

\begin{tabular}{|c|c|c|c|c|c|c|}
\hline \multirow[t]{2}{*}{$\begin{array}{c}\text { Jenis Produk } \\
\text { yang } \\
\text { Diiklankan }\end{array}$} & \multicolumn{2}{|c|}{$\begin{array}{c}\text { Frek. Konsumsi } \\
\text { (mingguan) } \\
\mathbf{n}=\mathbf{8 0}\end{array}$} & \multirow{2}{*}{$\begin{array}{c}\text { Partner } \\
\text { Konsumsi } \\
\text { Makanan } \\
\%\end{array}$} & \multirow{2}{*}{$\begin{array}{c}\text { Tempat } \\
\text { Makan } \\
\\
\%\end{array}$} & \multirow{2}{*}{$\begin{array}{c}\text { Frekuensi } \\
\text { Penayangan } \\
\text { Iklan di TV } \\
\text { (3 bulan) } \\
\% \%\end{array}$} & $\begin{array}{c}\text { Sumber } \\
\text { Informasi }\end{array}$ \\
\hline & $\mathbf{n}$ & $\%$ & & & & $\%$ \\
\hline \multicolumn{7}{|c|}{ Coklat dan Permen } \\
\hline Silver Queen & 12 & 15 & Sendiri (72) & Rumah (89) & 30 & TV (50) \\
\hline Relaxa & 39 & 49 & Teman (54) & Sekolah (45) & 102 & $\mathrm{TV}(78)$ \\
\hline Vicks & 40 & 50 & Teman (53) & Sekolah (43) & 100 & TV (70) \\
\hline \multicolumn{7}{|c|}{ Makanan Cepat Saji } \\
\hline KFC & 11 & 14 & Teman (52) & Semua: outlet & 108 & TV (63) \\
\hline Pizza Hut & 8 & 10 & Keluarga (69) & Makanan & 68 & TV (36) \\
\hline McDonald & 10 & 13 & Teman $(51)$ & Cepat Saji & 66 & TV (49) \\
\hline Mie & 54 & 65 & Sendiri (70) & Rumah (71) & 120 & TV (55) \\
\hline \multicolumn{7}{|c|}{ Minuman Ringan } \\
\hline Coca-Cola & 40 & 50 & Sendiri (44) & Sekolah (44) & 58 & TV (67) \\
\hline Teh Botol & 40 & 50 & $\begin{array}{l}\text { Teman (49) } \\
\text { Sendiri (52) } \\
\text { Teman (45) }\end{array}$ & $\begin{array}{l}\text { Resto (49) } \\
\text { Sekolah (45) } \\
\text { Resto (52) }\end{array}$ & 261 & TV (56) \\
\hline $\begin{array}{l}\text { Suplemen } \\
\text { Vitamin- } \\
\text { Mineral } \\
\text { Susu }\end{array}$ & 16 & 20 & Sendiri (80) & Rumah (80) & 40 & TV (28) \\
\hline
\end{tabular}




\section{Konsumsi Produk yang Diiklankan}

\section{Gambar 1. Distribusi Frekuensi Konsumsi Makanan/Minuman/Suplemen Vitamin- Mineral yang Diiklankan}

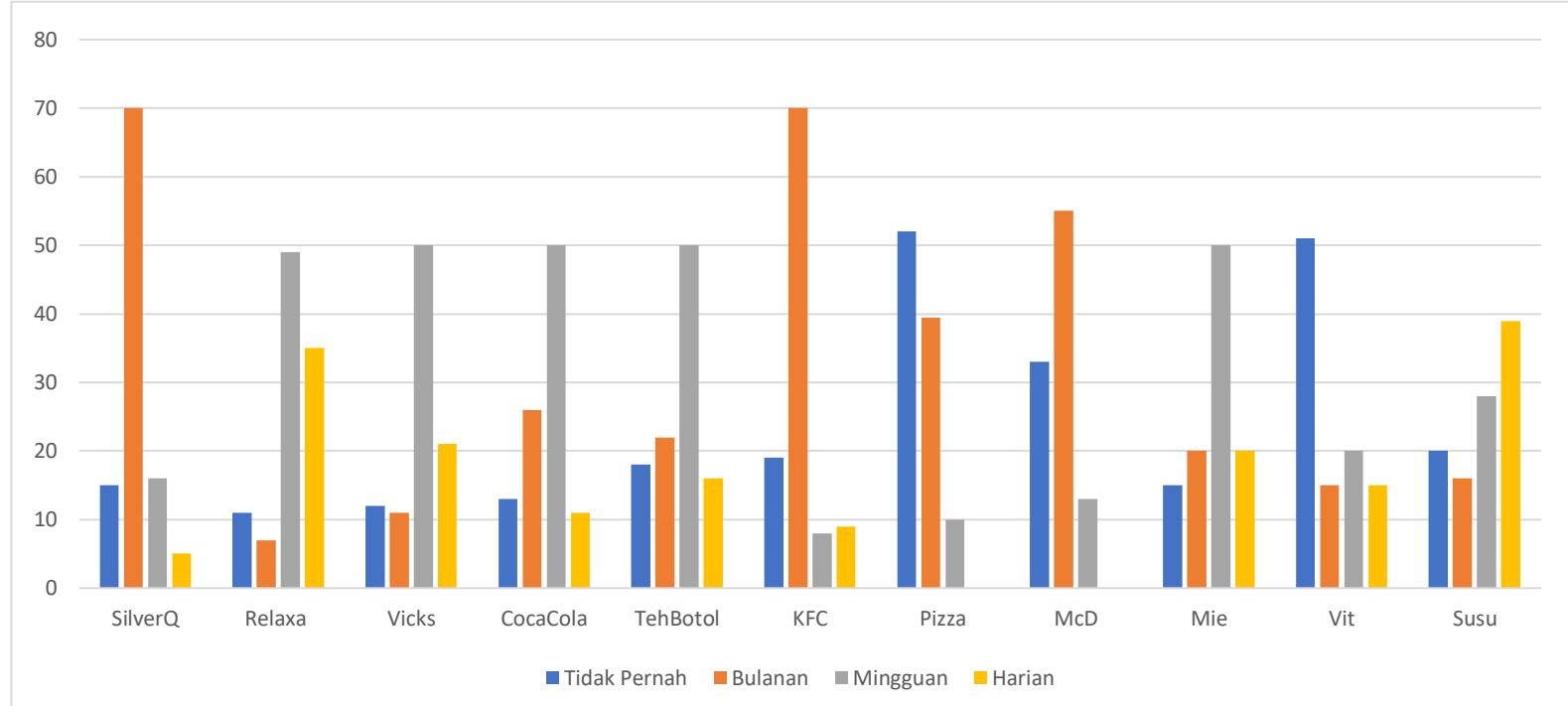

Gambar 1 menunjukkan bahwa makanan yang diiklankan dikonsumsi baik secara bulanan, mingguan atau harian tapi terutama dalam frekuensi mingguan. Dapat terlihat bahwa persentase frekuensi konsumsi makanan tertinggi adalah mie $(65 \%)$, CocaCola (50\%), Teh Botol (50\%), permen Relaxa (50\%) dan Vicks (50\%). Makanan cepat saji yang sering dikonsumsi setiap bulannya adalah KFC (68.8\%), Pizza (39\%) dan McDonald (54\%). Alasan responden mengkonsumsi produk yang diiklankan adalah karena "rasanya enak", "harga murah" (18.8\%) dan "disarankan oleh teman" (11.3\%). Sementara alasan untuk mengkonsumsi suplemen vitamin-mineral dan susu adalah "agar sehat" (43.8\%) dan “orangtua juga mengkonsumsinya” (27.5\%). Teh Botol dan Coca Cola dikonsumsi oleh $50 \%$ responden, tetapi minuman terfavorit di kalangan remaja adalah Coca Cola (66.3\%) sedangkan Teh Botol hanya disebutkan oleh 13.8\% remaja. Berdasarkan Tabel 1 dapat dilihat bahwa sebagian besar remaja mengkonsumsi produk yang diiklankan saat bersama teman-teman (permen dan makanan cepat saji). Permen terutama dikonsumsi di sekolah sedangkan coklat, mie, suplemen vitamin-mineral dan susu sebagian besar dimakan di rumah. Makanan cepat saji lebih sering dikonsumsi di restoran/outletnya masing-masing. Kemudian minuman ringan biasa dikonsumsi baik di restoran atau di sekolah. 
1. Hubungan Durasi Menonton TV terhadap Konsumsi Makanan/Minuman/Suplemen Vitamin-Mineral yang Diiklankan, Hobi Remaja dan Makan saat Menonton TV Tabel 2. Hubungan Antara Durasi Menonton TV per hari dan Konsumsi Makanan/Minuman/Suplemen Vitamin-Mineral yang Diiklankan

\begin{tabular}{|c|c|c|c|c|}
\hline \multirow{2}{*}{$\begin{array}{c}\text { Frekuensi Konsumsi } \\
\text { Makanan/Minuman/Suplemen } \\
\text { Vitamin-Mineral }\end{array}$} & \multirow[t]{2}{*}{$\mathbf{N}$} & \multicolumn{2}{|c|}{$\begin{array}{l}\text { Durasi Menonton TV per } \\
\text { hari (Median di Jam) }\end{array}$} & \multirow[t]{2}{*}{$\begin{array}{l}\text { Uji Mann- } \\
\text { Whitney }\end{array}$} \\
\hline & & $\begin{array}{c}25 \% \\
\text { persentil }\end{array}$ & $\begin{array}{c}75 \% \\
\text { persentil }\end{array}$ & \\
\hline \multicolumn{5}{|l|}{ Mie } \\
\hline Mingguan & 54 & 3 & $(3 ; 4)$ & \multirow[t]{2}{*}{$\mathrm{p}=0.05$} \\
\hline Harian & 15 & 4 & $(3 ; 4)$ & \\
\hline \multicolumn{5}{|l|}{ Pizza Hut } \\
\hline Bulanan & 31 & 3 & $(2 ; 4)$ & \multirow[t]{2}{*}{$\mathrm{p}=0.03$} \\
\hline Mingguan & 7 & 4 & $(3 ; 4)$ & \\
\hline \multicolumn{5}{|l|}{ Silver Queen } \\
\hline Bulanan & 52 & 3 & $(3,4)$ & \multirow[t]{2}{*}{$\mathrm{p}=0.44$} \\
\hline Mingguan & 15 & 4 & $(3,4)$ & \\
\hline \multicolumn{5}{|l|}{ Vicks } \\
\hline Mingguan & 41 & 3 & $(3,4)$ & \multirow[t]{2}{*}{$\mathrm{p}=0.79$} \\
\hline Harian & 16 & 3,5 & $(2.5,4)$ & \\
\hline \multicolumn{5}{|l|}{ Susu } \\
\hline Mingguan & 22 & 3 & $(3,4)$ & \multirow[t]{2}{*}{$\mathrm{p}=0.35$} \\
\hline Harian & 30 & 3,5 & $(3,4)$ & \\
\hline
\end{tabular}

Hasil Uji Mann-Whitney menunjukkan bahwa terdapat hubungan yang signifikan antara durasi menonton TV dengan frekuensi konsumsi mie dan Pizza Hut $(\mathrm{p}<0.005)$ (lihat Tabel 2). Semakin banyak remaja menonton TV, semakin sering pula mereka mengkonsumsi Pizza Hut secara bulanan dan mingguan. Terdapat juga tren positif antara durasi menonton TV dengan frekuensi konsumsi Silver Queen, Vicks dan susu. Semakin lama durasi menonton TV, semakin sering mereka mengkonsumsi Silver Queen, Vicks dan susu secara mingguan dan harian. Sementara remaja yang menonton TV sembari belajar lebih banyak mengkonsumsi Kentucky Fried
Chicken (KFC) dan Relaxa baik mingguan atau bulanan.

Terdapat hubungan positif antara durasi menonton TV dengan menghabiskan waktu untuk hobi. Semakin lama remaja meluangkan waktu untuk hobinya, durasi menonton TV mereka semakin sedikit. Namun Uji Kruskal Wallis menunjukkan bahwa durasi menonton TV tidak berhubungan secara signifikan dengan durasi menghabiskan waktu untuk melakukan hobi. Hampir seluruh responden makan saat mereka menonton TV (95\%) dan yang dikonsumsi adalah makanan ringan (59\%) dan mie (16\%). 
2. Hubungan antara Sikap terhadap Iklan dan Konsumsi Makanan/Minuman/Suplemen Vitamin-Mineral yang Diiklankan

Tabel 3. Asosiasi Antara Sikap Terhadap Iklan dan Konsumsi Makanan/Minuman/Suplemen Vitamin-Mineral yang Diiklankan

\begin{tabular}{lcccc}
\hline \multicolumn{1}{c}{ Pendapat } & \multicolumn{2}{c}{ Frekuensi Konsumsi } & Total & Uji Fisher-Exact \\
\cline { 2 - 3 } & Mingguan & Harian & & \\
\hline $\begin{array}{l}\text { Coca Cola } \\
\begin{array}{l}\text { Iklan TV menarik dan } \\
\text { memberikan informasi }\end{array}\end{array}$ & 17 & 4 & 21 & $\mathrm{p}=0.67$ \\
$\begin{array}{l}\text { Iklan TV mengganggu } \\
\text { Mie }\end{array}$ & 9 & 2 & 11 & \\
$\begin{array}{l}\text { Iklan TV selalu membuat } \\
\text { responden membeli } \\
\text { produk TV tidak selalu }\end{array}$ & 48 & 9 & 57 & $\mathrm{p}=0.03$ \\
$\begin{array}{l}\text { Iklan TV } \\
\text { membuat responden } \\
\text { membeli produk }\end{array}$ & 5 & 3 & 8 & \\
$\begin{array}{l}\text { Suplemen Vitamin-Mineral } \\
\text { Iklan TV selalu } \\
\text { mengatakan yang }\end{array}$ & 11 & 10 & 21 & $\mathrm{p}=0.44$ \\
sebenarnya & & & & \\
$\begin{array}{l}\text { Iklan TV tidak selalu } \\
\text { mengatakan kebenaran }\end{array}$ & 4 & 2 & 6 & \\
\hline
\end{tabular}

Terdapat beberapa faktor yang berhubungan terhadap iklan seperti sikap dan pengetahuan gizi. Berdasarkan hasil wawancara, responden berpendapat bahwa iklan bersifat "menarik dan informatif" $(43.8 \%)$ tetapi $63.8 \%$ sisanya berpikir bahwa iklan produk "tidak selalu mengatakan yang sebenarnya”. Uji FisherExact mengungkapkan bahwa terdapat hubungan positif antara frekuensi konsumsi mie dan iklan tersebut mampu menggugah mereka untuk membeli produk. Responden yang mengatakan bahwa iklan "tidak selalu membuat mereka membeli produk" (59\%) mengkonsumsi mie lebih sering daripada mereka yang mengatakan bahwa iklan "tidak membuat mereka membeli produk".

Terdapat tren positif antara konsumsi dan pendapat Coca-Cola terhadap iklan suplemen makanan TV / minuman / vitaminmineral. Responden yang mengatakan iklan makanan bersifat "menarik dan informatif" mengkonsumsi Coca-Cola lebih sering daripada mereka yang merasa terganggu dengan adanya iklan. Tren positif juga ditemukan antara responden yang setuju terhadap kebenaran iklan dengan konsumsi suplemen vitamin-mineral. Sedangkan pada remaja yang mengatakan iklan "tidak 
JURNAL ILMU KESEHATAN BHAKTI HUSADA:

HEALTH SCIENCES JOURNAL, Vol. 10 No. 01, JUNI 2019

DOI:
Ciptaan disebarluaskan di bawah Lisensi Creative Commons AtribusiNonKomersial-BerbagiSerupa 4.0 Internasional.

mengatakan kebenaran", lebih jarang Selain itu, gender tidak memiliki hubungan mengkonsumsi suplemen vitamin-mineral. yang signifikan dengan sikap terhadap iklan.

\section{Pengetahuan Gizi.}

Tabel 4. Hubungan antara Skor Pengetahuan Gizi dan Konsumsi Makanan/Minuman/Suplemen Vitamin-Mineral yang Diiklankan

\begin{tabular}{lccc}
\hline \multicolumn{1}{c}{ Frekuensi Konsumsi } & $\mathbf{N}$ & Skor Pengetahuan Gizi & Uji statistik \\
\cline { 1 - 2 } & & Mean \pm SD & \\
\hline Relaxa & 39 & $42.82 \pm 7.32$ & \\
$\quad$ Mingguan & 25 & $40.08 \pm 7.97$ & $\mathrm{p}=0.038$ \\
$\quad$ Harian & & & $\mathrm{t}=3.403$ \\
$\begin{array}{l}\text { Suplemen Vitamin-Mineral } \\
\quad \text { Mingguan }\end{array}$ & 16 & $43.93 \pm 8.49$ & $\mathrm{p}=0.04$ \\
$\quad$ Harian & 11 & $46.04 \pm 7.12$ & $\mathrm{~F}=4.42$ \\
\hline
\end{tabular}

Tabel 4 menunjukkan terdapat hubungan signifikan antara skor pengetahuan gizi dan konsumsi Relaxa $(\mathrm{p}=$ 0.038). Semakin tinggi skor pengetahuan gizi remaja, semakin sedikit mereka mengkonsumsi permen. Berdasarkan hasil Chi-Square juga terlihat bahwa ada hubungan signifikan antara skor pengetahuan gizi terhadap konsumsi suplemen vitamin-mineral. Remaja dengan skor pengetahuan gizi yang tinggi mengkonsumsi suplemen vitamin-mineral lebih sering.

\section{Hubungan Pengetahuan Gizi dengan Pekerjaan Orang Tua}

Meskipun terdapat perbedaan proporsi pengetahuan gizi di kalangan responden yang ibunya bekerja di kantor (24\%) dibandingkan dengan mereka yang ibunya adalah ibu rumah tangga (74\%), tetapi perbedaan ini tidak terbukti signifikan secara statistik. Pekerjaan ayah juga tidak berkaitan dengan pengetahuan gizi remaja, meskipun proporsi responden yang ayahnya bekerja sebagai pegawai negeri sipil (34\%) memiliki skor pengetahuan gizi tertinggi daripada pekerjaan lainnya. 
Status Sosial-Ekonomi terhadap Konsumsi Makanan/Minuman/Suplemen VitaminMineral yang Diiklankan

1. Jumlah Uang Saku

Tabel 5. Hubungan Antara Jumlah Uang Saku dengan Konsumsi Makanan/Minuman/Suplemen Vitamin-Mineral yang Diiklankan

\begin{tabular}{lcccc}
\hline \multicolumn{1}{c}{ Frekuensi Konsumsi } & $\mathbf{N}$ & \multicolumn{2}{c}{$\begin{array}{c}\text { Jumlah Uang Saku } \\
\text { (Median di Ribu) }\end{array}$} & \multirow{2}{*}{$\begin{array}{c}\text { Uji Mann- } \\
\text { Whitney }\end{array}$} \\
\cline { 3 - 3 } & & $\begin{array}{c}\mathbf{2 5 \%} \\
\text { persentil }\end{array}$ & $\begin{array}{c}\mathbf{7 5 \%} \\
\text { persentil }\end{array}$ & \\
\hline KFC & 55 & 10 & $(9 ; 14)$ & $\mathrm{p}=0.07$ \\
$\quad \begin{array}{l}\text { Bulanan } \\
\text { Mingguan }\end{array}$ & 11 & 10.5 & $(6 ; 20)$ & \\
$\begin{array}{l}\text { Relaxa } \\
\text { Mingguan }\end{array}$ & 39 & 10 & $(6 ; 14)$ & $\mathrm{p}=0.84$ \\
$\quad \begin{array}{l}\text { Harian } \\
\text { Vicks }\end{array}$ & 27 & 10.5 & $(8 ; 12)$ & \\
$\quad \begin{array}{l}\text { Mingguan } \\
\text { Harian }\end{array}$ & 40 & 10 & $(6 ; 14)$ & $\mathrm{p}=0.77$ \\
\hline
\end{tabular}

Hasil Uji Mann-Whitney menunjukkan bahwa frekuensi makan Kentucky Fried Chicken (KFC) berhubungan signifikan dengan jumlah uang saku (lihat Tabel 5, $\mathrm{p}=0.07)$. Terdapat hubungan positif antara jumlah uang saku dan frekuensi konsumsi permen (Relaxa, Vicks) dan Coca-Cola. Semakin banyak jumlah uang saku yang diterima, semakin sering mereka mengkonsumsi permen dan Coca-Cola.

\section{Gender}

Tabel 6. Hubungan Antara Gender dan Konsumsi Makanan/Minuman/Suplemen Vitamin-Mineral

\begin{tabular}{lcccc}
\hline \multicolumn{1}{c}{ Frekuensi Konsumsi } & \multicolumn{2}{c}{ Gender } & Total & P-Value \\
\cline { 2 - 3 } & Laki-laki & Perempuan & & \\
\hline Teh Botol & 23 & 17 & 40 & $\mathrm{p}=0.07$ (Fisher) \\
$\quad$ Mingguan & 8 & 3 & 11 & \\
$\quad$ Harian & 34 & 20 & 54 & $\mathrm{p}=0.08$ (Fisher) \\
Silver Queen & 10 & 2 & 12 & \\
$\quad$ Bulanan & & & & \\
$\quad$ Mingguan & 12 & 10 & 22 & $\mathrm{p}=0.07$ (Chi-Square) \\
$\quad$ Susu & 6 & 17 & 23 & \\
$\quad$ Mingguan & & & & \\
$\quad$ Harian & 7 & 9 & 16 & $\mathrm{p}=0.11$ (Fisher) \\
$\quad$ Suplemen Vitamin-Mineral & & & & \\
$\quad$ Mingguan & 2 & 10 & 12 & \\
$\quad$ Harian & & & & \\
\hline
\end{tabular}


JURNAL ILMU KESEHATAN BHAKTI HUSADA:

HEALTH SCIENCES JOURNAL, VOL. 11 NO. 01, JUNI 2020

DOI: 10.34305/jikbh.v11i1.152
Ciptaan disebarluaskan di bawah

Lisensi Creative Commons Atribusi-

NonKomersial-BerbagiSerupa 4.0 Internasional.
Perempuan cenderung lebih banyak mengkonsumsi susu dan suplemen vitaminmineral setiap hari dibandingkan laki-laki sementara laki-laki cenderung makan lebih banyak coklat (Silver Queen) dan minum Teh Botol (lihat Tabel 6). Secara umum, laki-laki menonton TV lebih lama daripada perempuan (lihat Tabel 7). Terdapat hubungan yang signifikan antara jumlah uang saku dengan gender $(\mathrm{p}=0.038)$. Perempuan mendapat uang saku yang lebih banyak daripada laki-laki tapi lebih banyak perempuan yang menyimpan uang saku mereka untuk ditabung (44\%). Gender secara signifikan berhubungan dengan skor pengetahuan gizi, di mana perempuan memiliki pengetahuan gizi yang lebih baik daripada laki-laki.

Tabel 7. Hubungan antara Gender dan Beberapa Faktor Terkait

\begin{tabular}{|c|c|c|c|}
\hline Gender & $\mathbf{N}$ & Faktor terkait & Uji statistik \\
\hline & & $\begin{array}{l}\text { Jumlah Uang Saku (Rp) } \\
\text { rata-rata }\end{array}$ & \\
\hline Laki-laki & 40 & 9000 & $\mathrm{p}=0.04$ \\
\hline \multirow{2}{*}{ Perempuan } & 40 & 10000 & $\mathrm{t}=4.34$ \\
\hline & & $\begin{array}{l}\text { Durasi Menonton TV (jam) } \\
\text { rata-rata }\end{array}$ & \\
\hline Laki-laki & 40 & 4 & $\mathrm{p}=0.14$ \\
\hline \multirow{2}{*}{ Perempuan } & 40 & 3 & $\mathrm{t}=2.23$ \\
\hline & & $\begin{array}{l}\text { Pengetahuan Gizi } \\
\text { Mean } \pm \text { SD }\end{array}$ & \\
\hline Laki-laki & 40 & $39.76 \pm 8.47$ & $\mathrm{p}=0.01$ \\
\hline Perempuan & 40 & $44.24 \pm 6.49$ & $t=6.64$ \\
\hline
\end{tabular}

\section{Peer Group (Teman Bermain)}

Tabel 8. Hubungan antara Durasi Menghabiskan Waktu dengan Teman dan Konsumsi KFC / Vicks

\begin{tabular}{lccc}
\hline \multicolumn{1}{c}{ Frekuensi Konsumsi } & \multicolumn{2}{c}{$\begin{array}{c}\text { Durasi Bermain dengan } \\
\text { Teman }\end{array}$} & $\begin{array}{c}\text { Uji Fisher- } \\
\text { Exact }\end{array}$ \\
\cline { 2 - 3 } & $\mathbf{2}$ jam / hari & $\mathbf{>}$ 3 jam / hari & \\
\hline KFC & 36 & 15 & $\mathrm{p}=0.03$ \\
$\quad$ Bulanan & 9 & 2 & \\
$\quad$ Mingguan & & & $\mathrm{p}=0.03$ \\
Vicks & 27 & 12 & \\
$\quad$ Mingguan & 14 & 4 & \\
Harian & & &
\end{tabular}


JURNAL ILMU KESEHATAN BHAKTI HUSADA:

HEALTH SCIENCES JOURNAL, VOL. 11 NO. 01, JUNI 2020 DOI: 10.34305/jikbh.v11i1.152
Ciptaan disebarluaskan di bawah

Lisensi Creative Commons Atribusi-

NonKomersial-BerbagiSerupa 4.0 Internasional.
Remaja menghabiskan waktu bersama teman sekitar 2-3 jam per hari. Pada umumnya mereka bertanding olahraga (36\%), mengobrol (37\%), belajar (17\%) dan makan bersama-sama (9\%). Terdapat hubungan antara menghabiskan waktu bersama teman (peer group) dengan frekuensi konsumsi Vicks, McDonald dan konsumsi KFC. Semakin lama remaja menghabiskan waktu bersama teman, semakin banyak mereka mengkonsumsi makanan cepat saji dan permen (lihat Tabel 8). Diketahui pula bahwa gender tidak berhubungan dengan durasi bermain bersama teman.

\section{Pembahasan}

\section{Durasi Menonton TV.}

Responden (siswa SMA) menonton TV rata-rata 28 jam dalam seminggu (43.8\%). Hal ini serupa dengan data dari Survei Indeks Mutu Nasional Program TV oleh Komisi Penyiaran Indonesia yang menyebutkan bahwa rata-rata remaja Indonesia menonton TV sebanyak 20 jam seminggu (KPI, 2017). Beberapa penelitian menyebutkan, semakin lama durasi remaja menonton TV maka semakin banyak mereka mengkonsumsi produk yang diiklankannamun mereka tidak mengkonsumsinya saat sedang menonton TV. Selama menonton TV, remaja cenderung mengkonsumsi makanan ringan tradisional seperti pisang goreng, roti manis dan kue-kue kecil.
Remaja yang memiliki kebiasaan menonton TV cenderung lebih banyak mengkonsumsi makanan yang tidak sehat serta lebih sedikit sayur dan buah (Collings, 2018). Durasi menonton TV telah terbukti berhubungan terhadap tingginya konsumsi snack, minuman, makanan cepat saji dan makanan manis (Pearson \& Biddle, 2011).

Beberapa penelitian telah secara konsisten menunjukkan bahwa banyaknya paparan iklan TV mampu meningkatkan daya konsumsi produk yang diiklankan, seperti makanan cepat saji atau minuman dengan kadar gula tinggi. Hal ini juga berkaitan dengan tingginya daya beli makanan, ketersediaan makanan yang diiklankan di rumah dan peningkatan asupan makanan pada umumnya (Busse \& Díaz, 2014). Beberapa alasan mengapa makanan diiklankan di TV adalah: produk makanan mampu mengikat daya beli konsumen, makanan adalah barang yang dapat dibeli berulang kali, pendapat konsumen terhadap produk cepat berubah dan makanan merupakan salah satu produk utama yang paling sering diiklankan (United Kingdom Advertising Association, 2014).

\section{Sikap terhadap Iklan.}

Remaja dapat pula menjadi skeptis terhadap iklan dan menyadari produk yang diiklankan tidak selalu sebagus yang ditampilkan(Mangleburg \& Bristol, 2013). Dalam penelitian ini, $63.8 \%$ remaja berpikir 
JURNAL ILMU KESEHATAN BHAKTI HUSADA:

HeALTH SCIENCES JOURNAL, Vol. 10 No. 01, JUNI 2019 DOI:

bahwa iklan makanan/minuman/suplemen vitamin-mineral "tidak selalu mengatakan yang sebenarnya". Penyebabnya adalah remaja sudah pernah mencoba produk tersebut namun ternyata tidak sebaik seperti yang terlihat di iklan. Selain itu, dapat terlihat bahwa ada hubungan positif antara pendapat terhadap iklan dan frekuensi konsumsi mie dan Coca-Cola. Para remaja yang merasa terganggu terhadap iklan di TV cenderung lebih sedikit mengkonsumsi mie dibandingkan remaja yang berpikir iklan TV sebagai "menarik dan informatif".

Tetapi remaja masih bisa dipengaruhi melalui iklan TV yang bersifat persuasif dan menggugah emosional sehingga dapat mendorong kekhawatiran mereka akan penampilan, identitas dan rasa kepemilikan diri. Remaja mungkin mengalami misinterpretasi terhadap iklan yang membuat mereka pada akhirnya membeli produk meskipun mereka mengatakan menonton iklan tidak selalu membuat mereka tergugah untuk membeli produknya (Sood A, 2015). Oleh karena itu dalam studi ini, meskipun responden mengaku bahwa iklan TV terlihat mengganggu, bukan berarti mereka tidak akan membeli produk tersebut sama sekali, karena citra iklan yang buruk pada dasarnya tidak begitu mempengaruhi motivasi pembelian.
Remaja yang berpikir bahwa iklan makanan "tidak selalu benar" cenderung mengkonsumsi mie dan suplemen vitaminmineral lebih sering dibandingkan dengan mereka yang berpikir iklan tersebut "tidak benar". Dalam penelitian ini, hanya beberapa siswa mengatakan bahwa iklan TV “selalu membuat mereka membeli produk". Hal ini menunjukkan bahwa meskipun mereka mengatakan iklan TV tidak selalu membuat mereka membeli produk, secara tidak langsung mereka mengakui bahwa tetap ada pengaruh dari iklan TV terhadap daya beli dan konsumsi.

Dalam penelitian ini, informasi terkait durasi berbagai jenis iklan makanan/minuman/suplemen vitaminmineral yang ditampilkan di TV selama tiga bulan menunjukkan bahwa semakin banyak produk disiarkan baik pada channel program favorit remaja atau channel keseluruhan maka semakin banyak frekuensi konsumsi. Makanan/minuman yang paling sering dikonsumsi adalah mie, Relaxa dan Teh Botol. Makanan tersebut memang paling banyak diiklankan selama penayangan program TV favorit remaja. Coca-Cola juga sering dikonsumsi oleh remaja, tetapi jauh lebih sedikit frekuensi penyiarannya (hanya 58 kali disiarkan dalam tiga bulan). Namun Coca-Cola telah diproduksi dan diiklankan sejak lama dibandingkan dengan Relaxa dan Teh Botol. 
JURNAL ILMU KESEHATAN BHAKTI HUSADA:

HeALTH SCIENCES JOURNAL, Vol. 10 No. 01, JUNI 2019

DOI:

Pengetahuan Gizi.

Pilihan makanan dipengaruhi oleh persepsi yang berkaitan dengan pengetahuan. Pengetahuan gizi berperan penting tidak hanya untuk pilihan makanan dan menyeimbangkan berat badan, tetapi juga untuk efek jangka panjang terhadap kesehatan secara umum. Studi sebelumnya telah mengatakan bahwa meskipun pilihan makanan pada masa remaja sering ditentukan oleh preferensi rasa, mereka masih memperhatikan jenis nutrisi yang terkandung pada makanan (Bargiota \& et al., 2013). Tabel 4 menunjukkan hubungan negatif antara konsumsi Relaxa dan pengetahuan gizi remaja. Semakin tinggi skor yang mereka punya (semakin luas pengetahuannya), semakin sedikit frekuensi konsumsi Relaxa. Sebaliknya, diketahui hubungan positif antara konsumsi suplemen vitamin-mineral dengan skor pengetahuan gizi. Semakin tinggi skor pengetahuan gizi yang mereka punya, semakin sering remaja mengkonsumsi suplemen vitamin-mineral.

\section{Status Sosial-Ekonomi}

\section{Jumlah Uang Saku}

Paparan iklan makanan di TV membuat remaja menghabiskan uang saku mereka untuk membeli makanan yang diiklankan dan akan menjadikan mereka konsumen tetap di masa depan (Scully, Wakefield, \& et al., 2012). Dalam penelitian ini, sebagian besar responden mengkonsumsi

makanan/minuman/suplemen vitamin-mineral yang diiklankan karena memiliki rasa yang enak (55\%) dan harga murah (18.8\%). Makanan yang lebih mahal harganya seperti Pizza Hut, lebih sering dikonsumsi bersama keluarga dibandingkan dengan produk lain yang lebih sering dikonsumsi sendiri dan saat bersama teman. Riset pasar mengungkapkan bahwa harga Pizza Hut yang lebih mahal dibandingkan produk lain menjadi alasan remaja untuk tidak membelinya dengan uang saku sendiri (Kurien, 2010). Secara umum, makanan cepat saji dikonsumsi secara bulanan. Hanya sekitar $10 \%$ yang mengkonsumsinya rutin tiap minggu.

\section{Gender}

Terdapat perbedaan fenomena antara laki-laki dan perempuan pada respon terhadap iklan TV melalui pola konsumsi. Pada perempuan, menonton TV tidak selalu membuat mereka makan lebih banyak. Iklan makanan yang tidak sehat juga lebih mempengaruhi anak laki-laki daripada perempuan, ditambah mereka tidak didukung oleh aspek pengetahuan (kognitif) 
JURNAL ILMU KESEHATAN BHAKTI HUSADA:

HeALTH SCIENCES JouRnAL, Vol. 10 No. 01, JUNI 2019

DOI:
Ciptaan disebarluaskan di bawah

Lisensi Creative Commons Atribusi-

NonKomersial-BerbagiSerupa 4.0

Internasional. gizi yang cukup. Frekuensi konsumsi makanan dan minuman tinggi kalori setelah menonton iklan TV meningkat pada laki-laki (Collings, 2018). Dalam studi ini persentase laki-laki yang mengkonsumsi Teh Botol (minuman) dan Silver Queen (coklat) lebih tinggi daripada perempuan, sekaligus laki-laki menonton TV lebih lama daripada perempuan. Sehingga dapat disimpulkan bahwa laki-laki cenderung lebih sering mengkonsumsi makanan rendah gizi daripada perempuan.

Studi lainnya mengatakan bahwa beberapa remaja perempuan mengkonsumsi snack selagi menonton TV, tetapi mereka menghindari snack yang terlalu manis atau asin. Penelitian ReyLopez et al. juga menunjukkan bahwa remaja laki-laki yang menonton TV lebih dari 4 jam memiliki risiko tinggi menjadi overweight (Rey-Lopez \& Ruiz, 2012). Sedangkan remaja perempuan cenderung mengkonsumsi suplemen vitamin-mineral lebih banyak daripada laki-laki, serupa dengan penelitian dari Perlitz et al. (Perlitz, Mensink, \& et al., 2019)yang mengatakan bahwa persentase konsumsi suplemen lebih tinggi pada perempuan (18.5\%) dibandingkan anak laki-laki (14\%). Alasan mengapa remaja mengkonsumsi suplemen adalah agar sehat (44\%), orangtua mereka juga mengkonsumsinya (28\%) dan saran dokter $(5 \%)$, tetapi hanya $2 \%$ remaja perempuan yang mengkonsumsi suplemen dari resep dokter. Studi Perlitz et al. mengatakan bahwa alasan remaja minum suplemen adalah untuk meningkatkan kesehatan, pencegahan defisiensi gizi atau rekomendasi dokter (Perlitz et al., 2019). Selain itu, terdapat hubungan antara nilai pengetahuan gizi dengan gender. Perempuan mendapat nilai yang lebih tinggi daripada laki-laki. Tingkat pengetahuan gizi yang lebih tinggi dapat menjadi faktor yang berhubungan dengan konsumsi makanan yang lebih bergizi.

\section{Peer Group (teman bermain)}

Makanan merupakan media universal untuk mengekspresikan sosialisasi dan kenyamanan. Teori Hierarki Kebutuhan dari Maslow mengatakan bahwa kebutuhan sosial adalah motivator umum yang utama dari perilaku manusia (Taormina \& Gao, 2013). Remaja yang 
JURNAL ILMU KESEHATAN BHAKTI HUSADA:

HeALTH SCIENCES JouRnAL, Vol. 10 No. 01, JUNI 2019

DOI:
Ciptaan disebarluaskan di bawah

Lisensi Creative Commons Atribusi-

NonKomersial-BerbagiSerupa 4.0

Internasional. menghabiskan banyak waktu dengan teman-teman sembari makan, mampu membangun ikatan sosial dan mengembangkan pemahaman tentang norma/budaya tentang makanan dan pola makan (Howland, Hunger, \& Mann, 2012). Hasil studi menunjukkan bahwa responden cenderung menghabiskan waktu bersama teman untuk makan bersama (9\%) dan salah satu alasan responden mengkonsumsi makanan yang diiklankan adalah "Temanteman mengajak untuk makan bersama atau berbagi makanan" (11\%) dan untuk "family gathering" (6\%). Meskipun persentasenya cukup kecil, tetapi dapat dilihat pada Tabel 1 bahwa mayoritas responden mengkonsumsi makanan yang diiklankan saat bersama temantemannya. Relaxa, Teh Botol dan Coca-Cola adalah makanan yang umum dimakan saat mereka kumpul bersama. Hal ini disebabkan mereka menyukai rasanya, produk tersebut mudah dijumpai di kantin sekolah dan dikonsumsi pada jam istirahat bersama teman-teman. Pada kasus ini, makanan berfungsi sebagai kebutuhan sosial.

\section{Kesimpulan}

Remaja di Jakarta Timur yang menonton TV sekitar 28 jam seminggu terpapar iklan makanan/minuman/suplemen vitamin-mineral sebanyak 6 menit per jam. Terdapat hubungan antara durasi menonton TV terhadap pola konsumsi remaja. Semakin lama durasi remaja menonton TV maka semakin banyak frekuensi konsumsi makanan/minuman/suplemen vitaminmineral yang diiklankan. Namun dikarenakan frekuensi konsumsi produk yang diiklankan masih secara bulanan dan mingguan, dapat disimpulkan bahwa hal itu belum menjadi faktor resiko gizi pada kelompok remaja tersebut.

Sikap/persepsi positif terhadap iklan, jumlah uang saku serta durasi bermain dengan teman juga menunjukkan tren positif yaitu semakin banyak frekuensi konsumsi makanan/minuman/suplemen vitaminmineral yang diiklankan. Semakin banyak uang saku dan semakin lama waktu bermain bersama teman, maka semakin banyak frekuensi konsumsi produk yang diiklankan. Sedangkan pengetahuan gizi diketahui berhubungan terhadap pilihan makanan yang lebih bergizi.

Berdasarkan gender, laki-laki cenderung mengkonsumsi makanan yang lebih rendah gizi dibandingkan perempuan, sedangkan perempuan cenderung lebih 
JURNAL ILMU KESEHATAN BHAKTI HUSADA:

HeALTH SCIENCES JOURNAL, Vol. 10 No. 01, JUNI 2019 DOI:

banyak mengkonsumsi suplemen vitaminmineral ketimbang laki-laki.

\section{Referensi}

Arcan, C., Bruening, M., \& Story, M. (2014). Television (TV) and TV Advertisement Influences on Children ' s Eating Behaviour. Encyclopedia on Early Childhood Development, 1-7. Retrieved from http://www.childencyclopedia.com/Pages/PDF/ArcanBruening-StoryANGxp1.pdf

Bargiota, A., \& et al. (2013). Eating Habits and Factors Affecting Food Choice of Adolescents Living in Rural Areas. Hormones, 12(2), 246-253. https://doi.org/10.14310/horm.2002.14 08

Busse, P., \& Díaz, R. (2014). What Are the Television Viewing and Eating Habits of Children in Peru? https://doi.org/10.1177/175797591454 7923

Collings, P. J. (2018). Associations of TV Viewing Duration, Meals and Snacks Eaten When Watching TV, and a TV in the Bedroom with Child Adiposity. 26(10), 1619-1628.

https://doi.org/10.1002/oby.22288

Eni-harari, T. Te, \& Eyal, K. (2019). The Role of Food Advertising in Adolescents ' Nutritional Health Socialization The Role of Food Advertising in Adolescents ‘
Nutritional Health Socialization.

Health Communication, O(0), 1-12. https://doi.org/10.1080/10410236.2019 .1598737

Eyal, K., \& et al. (2016). High on attractiveness, low on nutrition: An over-time comparison of advertising food products on Israeli television. Journal of Health Communication.

Howland, M., Hunger, J., \& Mann, T. (2012). Friends Don`t Let Friends Eat Cookies: Effects of Restricting Eating Norms of Consumption among Friends. Appetite, 59, 505-509.

Hurlock, E. . (n.d.). Developmental Psychology - A Life Span Approach. New York: McGraw-Hill Publishing Company Ltd.

Kemenkes RI. (2014). Riset Kesehatan Dasar 2013.

KPI. (2017). Hasil Survey Indeks Kualitas Program Siaran Televisi Periode II Tahun 2017.

Kurien, D. (2010). Restaurant Image Parameters and its Importance in Building Children's Perception for Multinational Fast Food Restaurants.

Mangleburg, T., \& Bristol, T. (2013). Socialization and Adolescents' Skepticism toward Advertising. Journal of Advertising, 27(3), 11-21.

Pearson, N., \& Biddle, S. (2011). Sedentary behavior and dietary intake in children, 
JURNAL ILMU KESEHATAN BHAKTI HUSADA:

HEALTH SCIENCES JOURNAL, Vol. 10 No. 01, JUNI 2019 DOI:

adolescents, and adults : A systematic review. American Journal of Preventive Medicine, 41, 178-188.

Perlitz, H., Mensink, G. B. M., \& et al. (2019). Use of Vitamin and Mineral Supplements among Adolescents Living in Germany. Journal of Nutrients, $\quad 11(1208), \quad$ 2-12. https://doi.org/10.3390/nu11061208

Rey-Lopez, J., \& Ruiz, J. (2012). Physical activity does not attenuate the obesity risk of TV viewing in youth. Journal of Pediatric Obesity, 7(240-250).

Richard, M. L., Paul, K., \& Anne-marie, N. (2017). Influence of mass media on family planning methods use among couples in Gashenyi Sector Rwanda Influence of mass media on family planning methods use among couples in Gashenyi Sector Rwanda. (June).

Scully, M., Wakefield, M., \& et al. (2012).
Association Between Food Marketing Exposure and Adolescents' Food Choices and Eating Behaviors. Appetite, $\quad 58(1), \quad$ 1-5. https://doi.org/10.1016/j.appet.2011.09 .020

Sood A, B. G. (2015). Effects of Advertising on Youth (Age Group of 13-19 Years Age). Journal of Mass Communication \& Journalism, 05(05). https://doi.org/10.4172/2165-

7912.1000260

Taormina, R. J., \& Gao, J. H. (2013). Maslow and the Motivation Hierarchy: Measuring Satisfaction of the Needs. 126(2), 155-177.

United Kingdom Advertising Association. (2014). Understanding Food Advertising.

WHO. (2017). Obesity and Overweight: Fact Sheet. 